\title{
大動脈炎症候群および混合性結合組織病に 合併する肺高血圧症の比較
}

\author{
斎藤 美和子・宮田昌之・松 喜 博 記・武 田功 \\ 渡 辺 浩・木田さとみ・海 瀬 俊 治 \\ 大原 守弘・西間木 友 衛・粕川禮 司
}

Jpn. J. Clin. Immun., 17 (3) : 147 151, 1994.

\section{Comparison between aortitis syndrome and mixed connective tissue disease associated with pulmonary hypertension}

\author{
Miwako Saito, Masayuki Miyata, Hiroki Matsuzaki, Isao Takeda, \\ Hiroshi Watanabe, Satomi Kida, Shunji Kaise, \\ Morihiro Ohhara, Tomoe Nishimaki and Reiji Kasukawa
}

Department of 2nd Internal Medicine, Fukushima Medical College

\section{【Summary】}

Aortitis syndrome (AoS) associated with pulmonary hypertension ( $\mathrm{PH})$ is rare. Patients of AoS associated with PH are milder than those of mixed connective tissue disease (MCTD) with $\mathrm{PH}$.

We measured the anticardiolipin antibody (aCL) in the plasma of 10 patients with AoS and 17 patients with mixed connective tissue disease (MCTD), and tried to find out whether it correlates with PH. All two patients with AoS and PH were negative for aCL, on one hand all three patients with MCTD and PH were positive for it. Two cases of AoS complicated with $\mathrm{PH}$ were reported. In case $1, \mathrm{PH}$ appeared 14 years after the diagnosis of AoS and the patient has been followed up as an outpatient for 6 years. In case 2, PH appeared 6 years after the diagnosis of AoS and the patient died of cardiac failure by the complication of $\mathrm{PH}$ after 6 years. The survival periods in patients with AoS and PH, and MCTD and PH were over five and 0.8 years, respectively.

We consider that the mechanism of PH between AoS and MCTD are different and the difference of it has influence on their prognosis. 
Key words : aortitis syndrome, pulmonary hypertension, anticardiolipin antibody, mixed connective tissue disease

\section{【概 要】}

大動脈炎症候群 (AoS) に肺高血圧 (PH) を合併するのはまれであり，また混合性結合組織病 (MCTD) に 合併するPHに比べて軽症のことが多い. 今回PHと抗カルジオライピン抗体 (aCL) との関係を AoS と MCTDについて比較検討した.さらにわれわれが経験したPH を合併した AoS 2 例を提示した.

$\mathrm{aCL}$ は, PH 合併 AoS 2 例でいずれも陰性であり，PH 合併 MCTD 3 例ではすべて陽性であった．症例 1 は $\mathrm{AoS}$ と診断 14 年後に PH を合併し, その後 6 年経過し生存中である. 症例 2 は AoS と診断 6 年後にPH を発 症しその 6 年後に死亡した. PH 発症後の生存期間は, AoS では 5 年以上, MCTD では平均 0.8 年であった。

AoS と MCTD では，PH は異なる機序で発症し，その予後の違いに関係すると考えられた。

\section{I 、はじめに}

大動脈炎症候群 (AoS) は, 約 70\%に肺動脈病変 を合併するが，肺高血圧症 $(\mathrm{PH})$ を呈するのはまれ であり，軽症のことが多い文。一方，泿合性結合組織 病 (MCTD) では，PHは，4\%とまれではあるが， 合併すれば，予後不良因子となる2). MCTDに拉

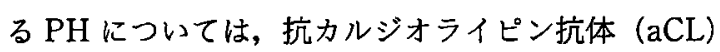
との関連が指摘されている3). 今回 AoS と MCTDに おける肺動脈病変と $\mathrm{aCL}$ 抗体価について比較検討し たので報告する. また，PH を合併した AoS の 2 症 例も合わせて提示する.

\section{II. 对象と方法}

福島県立医科大学付属病院第 2 内科にて経過観察中 のそれぞれ厚生省の診断基準4,5)を満たす AoS 10 例 と, MCTD 17 例を対象に, 平均肺動脈圧, 肺血流シ ンチおよび aCLについて retrospectiveに比較検討し た。

平均肺動脈圧は, AoS 2 例と MCTD 1 例は心蔵力 テーテルで，他は心エコーにて測定した．いずれか一 方にて平均肺動脈圧が $25 \mathrm{mmHg}$ 以上の症例を $\mathrm{PH}$ 合 併例とした.

aCL の測定はLoizouの酵素抗体法（ELISA）に 準じて測定しだ).すなうち，cardiolipin 抗原 (Sigma 社) $50 \mu \mathrm{g} / \mathrm{ml}$ の濃度で固相化し， $10 \%$ fetal calf serum 加 PBS で 200 倍希釈した活動期の血 清を加え測定した。 $20 \mathrm{U} / \mathrm{m} l$ 以上を陽性とした。

\section{III. 結 果}

\section{AoS と MCTD における平均肺動脈圧と肺血流 シンチについて}

表1に示すように，AoS 10 例中 2 例（20\%）に $\mathrm{PH}$ の合併を認めた. 肺血流シンチは, AoS 10 例中 6 例に施行した. $\mathrm{PH}$ を合併している症例 1 と症例 2 では, 多発性血流欠損を認めた。 $\mathrm{PH}$ を合併していな いと考えられた症例にて検査施行 4 例のうち, 2 例に 血流欠損を認めた。

MCTDでは，PH と診断されたのは 17 例中 3 例 （18\%）であった．肺血流シンチは，5例に施行した。 症例 9 は, 平均肺動脈圧は $86 \mathrm{mmHg}$ であり, 多発性 血流欠損を呈していた. 症例 5, 症例 10 は, 肺動脈 圧は正常だが, 血流シンチにては, 軽度の異常があっ た。

\section{PH の有無と抗カルジオライピン抗体との関係} 平均肺動脈圧と $\mathrm{aCL}$ の両方が測定された AoS 14 例と MCTD 11 例につき PH の有無と $\mathrm{aCL}$ との関係 を調べた。表 2 に示したごとく AoSでは, PH の有 無にかかわらず 4 例すべてで aCL は陰性であった。 一方, MCTDではPH を合併した 3 例はいずれも $\mathrm{aCL}$ が陽性であり，PH を合併しない 8 例中 1 例のみ が $\mathrm{aCL}$ 陽性であった。

\section{3. 症 例}

症例 $1: 42$ 歳, 女性, 主婦。

主 訴: 呼吸困難, 前胸部痛. 
表 $1 \mathrm{AoS}$ と MCTDにおける肺動脈圧と肺血流 シンチ

\begin{tabular}{|c|c|c|c|}
\hline & 症例 & $\begin{array}{c}\text { 平均肺動脈圧 } \\
(\text { 心エコー) } \\
\mathrm{mmHg}\end{array}$ & 肺血流シンチ \\
\hline \multirow{10}{*}{$\begin{array}{l}\text { 大動脈炎 } \\
\text { 症候群 }\end{array}$} & 1 & 33 & 多発性血流欠損 \\
\hline & 2 & 60 & 多発性血流欠損 \\
\hline & 3 & nd & 右中肺野血流欠損 \\
\hline & 4 & nd & nd \\
\hline & 5 & nd & 両下肺野血流欠損 \\
\hline & 6 & 18 & 正常範囲 \\
\hline & 7 & nd & 正常範囲 \\
\hline & 8 & nd & nd \\
\hline & 9 & nd & nd \\
\hline & 10 & 16 & nd \\
\hline \multirow{17}{*}{$\begin{array}{l}\text { 混合性結合 } \\
\text { 組織病 }\end{array}$} & 1 & nd & nd \\
\hline & 2 & 12 & 正常範囲 \\
\hline & 3 & 19 & nd \\
\hline & 4 & 22.5 & 正常範囲 \\
\hline & 5 & 15 & 下肺野血流欠損 \\
\hline & 6 & 16 & nd \\
\hline & 7 & 34 & nd \\
\hline & 8 & nd & nd \\
\hline & 9 & 86 & 多発性血流欠損 \\
\hline & 10 & 21.4 & 左肺血流低下 \\
\hline & 11 & 20 & nd \\
\hline & 12 & nd & nd \\
\hline & 13 & nd & nd \\
\hline & 14 & nd & nd \\
\hline & 15 & 49 & nd \\
\hline & 16 & 16 & nd \\
\hline & 17 & nd & nd \\
\hline
\end{tabular}

せ心カテにて測定, nd : not done

\section{既往歴：壊死性膿皮症（37 歳時）.}

現病歴：28 歳時（1974 年）に原因不明の発熱あり。 29 歳時に, 耳鳴り, 左手のだるさ，上肢の血圧の左 右差を指摘され当科入院. 炎症反応高値と血管造影の 所見から AoS と診断され，副腎皮質ステロイド剤と アザチオプリンによる治療を受け症状は軽快した。外
表 $2 \mathrm{AoS}$ と MCTD における平均肺動脈圧と $\mathrm{aCL}$ の関係

\begin{tabular}{|c|c|c|}
\hline $\begin{array}{l}\text { aCL } \\
\text { 平均 } \\
\text { 肺動脈圧 }\end{array}$ & $20 \mathrm{U} / \mathrm{m} l$ 未満 & $20 \mathrm{U} / \mathrm{m} l$ 以上 \\
\hline $25 \mathrm{mmHg}$ 末満 & $\begin{array}{l}00 \\
09000\end{array}$ & - \\
\hline $25 \mathrm{mmHg}$ 以上 & $\mathrm{O}^{*} \mathrm{O}^{*}$ & 000 \\
\hline $\begin{array}{l}0: \text { AoS } \\
: \text { MCTD }\end{array}$ & & \\
\hline
\end{tabular}

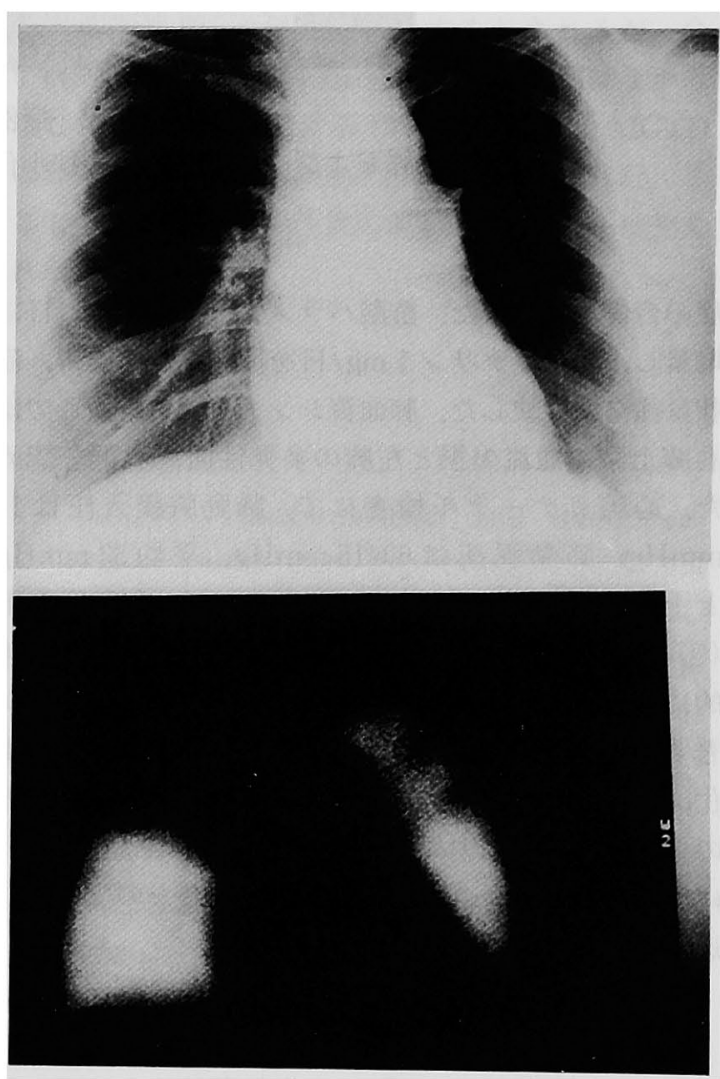

図 1 症例 1 の胸部X線単純写真（上段）と 肺血流シンチ (下段)

左 2 弓の突出, 両上肺野血管陰影の消失と 右肺門部血管陰影の増強が認められ，肺血流 シンチにて右上肺野の完全欠損と左上肺野の 多発性血流低下が認められた。

来にて経過観察されていたが，1988 年 5 月から労作 時呼吸困難と前胸部痛が出現し，6月当科に再入院と なった. 胸部 X線単純写真 (図 1 上段) では，心胸郭 比は $46 \%$, 左 II 弓の突出があり, 両上肺野血管陰影 の減少と右肺門血管陰影の増強が認められ，肺高血圧 


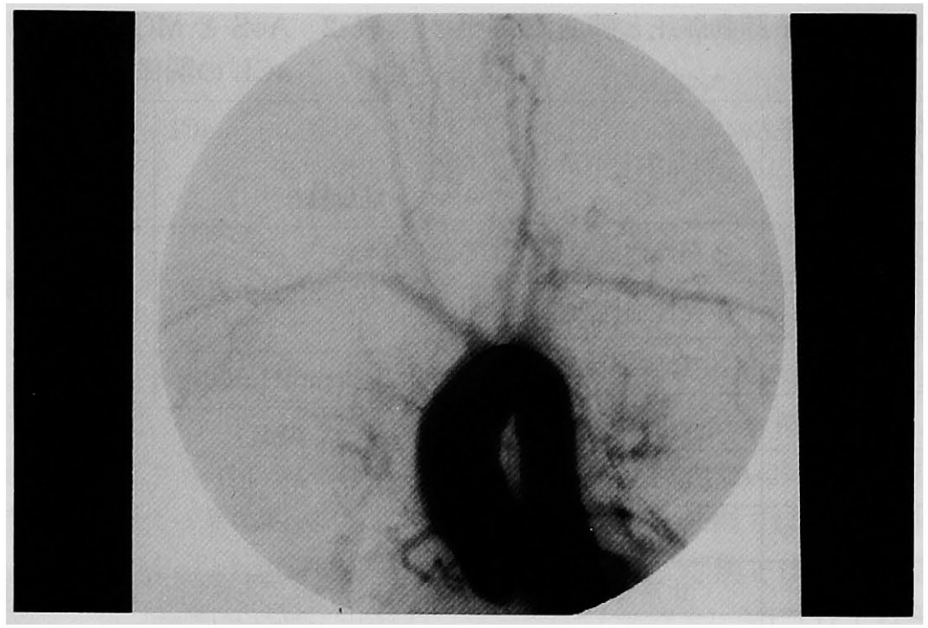

図 2 症例 1 の大動脈造影

両総䅡動脈および両鎖骨下動脈の狭小化と内径の不整が認められた，側副血行路の発達 が目立った。

症の合併が疑われた．酢酸パラメ்タゾンを $4 \mathrm{mg} /$ 日に 増量しワーファリン $1 \mathrm{mg} /$ 日を投与したところ, 症 状は徐々に軽快した。肺血流シンチ（図 1 下段）では 右肺上葉の血流欠損と左肺の多発性血流低下を認め た。，臓カテーテル検查にて，肺動脈楔入圧は 14 $\mathrm{mmHg}$, 肺動脈圧は $60 / 15 \mathrm{mmHg}$, 平均 $33 \mathrm{mmHg}$ と上昇しており，PH が合併していた．大動脈造影 （図 2）にては，大動脈弓から分岐する大血管が全体 的に細く, 内径が不規則であり, 側副血行路の発達が 著明であった，肺動脈造影では，右上幹動脈の狭小 化, 左肺動脈幹の突出, 内腔の拡大および左上肺動脈 の狭小化が認められた．呼吸困難と前胸部痛は，PH によるものと診断された．症状が安定したので 7 月に 退院. 以後他院にて経過観察中である.

症例 $2 ： 47$ 歳, 女性, 主婦。

主 訴: 呼吸困難.

既往歴：肺結核 (43 歳時)，慢性関節リウマチ (45 歳より罹患)。

現病歴：1980 年（39 歳時）に動悸と鈿量が出現。 右上肢の脈が触れず, AoS と診断され, 副腎皮質ス テロイド剤とアザチオプリンで加療され，入退院を繰 り返していた。 1986 年頃より労作時の呼吸困難と動 悸が出現し徐々に増悪した．第 2 心音の元進があり， 胸部 X線単純写真にて左第 II 弓の突出を認め $\mathrm{PH} の$ 合併が疑われて 1987 年 8 月入院となった.

心電図で，右軸偏位，右室肥大および肺性 $\mathrm{P}$ 波を認 めた。胸部X線単純写真にて CTR 57\%，右 II弓，左
II弓，IV弓の突出が認められた，心エコーにて右心室 壁の肥厚, 内腔の著明な拡大および右室流路の拡大が みられたが，弁膜に異常は認められなかった。肺血流 シンチでは, 左肺に多発性の血流欠損があり, 右肺も 全体的に血流が低下していた。強心利尿剤にて症状は 軽快した。心臓カテーテル検查にて肺動脈圧は 116/ $20 \mathrm{mmHg}$, 平均 $60 \mathrm{mmHg}$ と重度の $\mathrm{PH}$ が認められ た.肺動脈契入圧は， $46 \mathrm{mmHg}$ と高值であったが, 大動脈弁閉鎖不全症はなかった，造影剤に対する過敏 性があり，血管造影は施行できなかった，症状は一時 的に軽快し退院したが，その後心不全症状は徐々に進 行し低酸素血症が強くなり，在宅酸素療法を併用し た. 1993 年 1 月自宅にて死亡しているのを発見され た. 死因は肺高血圧症による心不全と考えられたが, 剖検は施行されなかった。

\section{IV. 考 察}

AoS は，主として大動脈弓部や腹部大動脈に炎症 が起こり，狭窄や動脈瘤を形成する原因不明の炎症性 疾㭧である。炎症の部位は，弾性動脈である大血管の 中膜・外膜が中心である7，肺動脈病変は AoS のほほ $70 \sim 80 \%$ に合併するといわれている8). その中で $\mathrm{PH}$ を呈するのは，Lupi ら9によれば，22例中 6 例 （27\%）で，その程度は軽く，PHによる症状を呈す るものは少ないと報告されている。症例 1 は AoS 発 症後 14 年で軽度の肺高血圧が認められ，その 6 年後 も $\mathrm{PH}$ は進行せず外来にて経過観察されている. 症 
例 2 は, AoS 発症 6 年後に心不全症状を訴え，その 2 年後に心缄カテーテル㭘査にて重度の $\mathrm{PH}$ を指摘 され，その 6 年後に自宅にて死亡した. AoS と診断 されてから $\mathrm{PH}$ を発症するまで症例 1 で 14 年, 症例 2 で 6 年と長く, いずれも $\mathrm{PH}$ 発症後 5 年以上生存 していた。一方, MCTDでは発症から PH 合併まで の平均年数は 5.6 年で, PH 合併から死亡までは 0.8 年 $^{\left({ }^{0}\right)}$ と短く, AoS と比較して発症後の経過は急激で 予後は不良であった. AoS の肺動脈病変は, 直径 1 $\mathrm{cm}$ 以上の弾性動脈に分節性, 散在性に形成され, 中 枢側の比較的太い血管に徐々に進行するため, 側副血 行路が発達し，PH は軽度にとどまるといわれてい $ろ^{11}$.

MCTD では, PH は, 合併率 4\% と低頻度ではあ るが，重篤な場合が多く，予後決定因子として重視さ れている ${ }^{2,10)}$. MCTD の肺動脈病変は，他の膠原病と 同様，末梢の筋性動脈の内膜と中膜に広範に形成され ている ${ }^{11)}$ AoS と比較すると MCTD では末梢小血管

1）石川嘉市郎・中尾訓久 - 浅井信明 - 他 2 名：閉 塞性凝血性大動脈症（いわゆる高安病）におけ る肺循環. 血液と脈管, $7: 603 \sim 618,1976$.

2）宮脇昌二・粕川禮司・西間木友衛・他 1 名：混 合性結合組織病の治療・予後アンケート一最終 集計，厚生省特定疾患・混合性結合組織病調查 研究班 - 昭和 62 年度研究報告書. 31 41, 1987.

3) Miyata, M., Kida, S., Suzuki, K. et al. : Pulmonary hypertension in MCTD : Report of two cases with anticardiolipin antibody. Clin. Rheumatology, 11: 195 201, 1992.

4）大動脈炎症候群診断の手引き．厚生省特定疾患 大動脈炎症候群調查研究班, 38, 1974.

5）粕川禮司・東條 毅 - 宮脇昌二・他：混合性結 合組織病診断の手引き，厚生省特定疾患混合性 結合組織病調查研究班昭和 58 年度研究報告書, $79 \sim 82,1984$.

6) Loizou, S., McCrea, J.D., Rudge, A.C. et al. : Measurement of anti-cardiolipin antibodies by an enzyme-linked immunosorbent assay
の広範な血管病変が主体であり, 側副血行路が発達で きず，重篤な症状を呈すると考えられる.

肺動脈障害の原因として，血管揫縮，免疫複合体の 沈着や血栓形成などがあげられている，膠原病の血管 内膜の障害と血栓症との関係で抗リン脂質抗体症候群 が近年注目されているが, 抗リン脂質抗体は血管内皮 細胞の抗血栓作用を障害し血栓を形成すると考えられ ている ${ }^{12)}$. 今回, $\mathrm{aCL}$ を当科の MCTD と AoS で測 定し，PH との関係について検討したが，MCTDに おいて aCL 陽性例は PH を合併する確率が高かった。

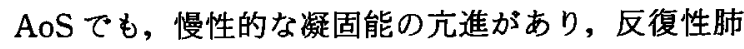
血栓塞栓症が PH の発症に関与するとされるが, 今 回の検討では, $\mathrm{PH}$ 合併 $\mathrm{AoS} に \mathrm{aCL}$ 陽性例はなかっ たことから，AoSにおける $\mathrm{PH}$ の発症には，MCTD とは異なる機序で血栓塞栓が生じると考えられた。こ のことがPH 発症後の予後の違いに関係すると考え られた。

(ELISA) : standardization and quantification of results. Clin. Exp. Immunol., $62: 738$ $\sim 745,1985$.

7）斉藤 建：高安動脈炎の病理解剖所見, 大動脈 炎症候群調查研究班・昭和 48 年研究報告書, p. 9, 1974.

8) 沼野藤夫: 高安病の肺動脈病変. 循環器科, $6: 97 \sim 108,1979$.

9) Lupi, H.E., Sanchez, T.G., Horwitz, S. et al. : Pulmonary artery involvement in Takayasu's arteritis. Chest., $67: 69 \sim 74,1972$.

10）粕川禮司：混合性結合組織病診断基準の妥当性 とその限界. Med. Immunol., 16:479 484, 1988.

11）沢井高志・京極方久：膠原病における肺の血管 病変一肺高血圧症との関係において一，呼と 循, $34: 59 \sim 67,1986$.

12）海瀬俊治・西間木友衛：臨床症状としての血栓 症の特徵は何か.リウマチ科, $5: 397 \sim 402$, 1991. 